e-mail: dargry@uw.edu.pl

Wydział Dziennikarstwa, Informacji i Bibliologii

Uniwersytetu Warszawskiego

\title{
HOTSPOTY W BIBLIOTEKACH - JAK BARDZO POWSZECHNE, JAK BARDZO POTRZEBNE?
}

\begin{abstract}
A period, in which getting the access to the Internet at the library required using the computer belonging to the library, and most often wired connected to the network, is ending. More and more libraries are giving users an alternative and more convenient way to use the Internet - access through wifi. All the more, it is possible to use the past tense while talking about the period when one should pay a fee for the access to the Internet in the library. Also, the expression "hotspots in libraries" has recently gained a new meaning. This is because among the items lent by libraries, alongside books and audiovisual materials, there appeared also portable devices called hotspots. They allow users to connect their mobile devices to the Internet practically from the any place - of course also beyond the library. In the article an attempt was made to answer the question of how common it has become in libraries to share the Internet wireless and by what rules it is being realized.
\end{abstract}

Slowa kluczowe: hotspoty w bibliotekach, Internet w bibliotece, Wi-Fi w bibliotece, bezprzewodowy Internet w bibliotece.

O tym, jak ważnym udogodnieniem w pracy naukowej i studiowaniu jest możliwość symultanicznego korzystania ze zbiorów bibliotecznych i zasobów Internetu, nie trzeba chyba nikogo przekonywać. Dostęp do Internetu w bibliotece jest usługą oczekiwaną przez większość użytkowników bibliotek. Są oczywiście osoby, którym podczas pracy w bibliotece brak dostępu do Internetu nie będzie szczególnie doskwierał, ale bez wątpienia w pracy naukowej pojawia czasem potrzeba konsultacji bibliograficznej albo językowej, a najprościej i najszybciej można zrobić to online, korzystając $z$ wiarygodnych, a dostępnych w sieci bibliografii, opracowań biograficznych i wydawnictw leksykograficznych.

Są też zapewne osoby, które w bibliotece chcą przede wszystkim korzystać ze zgromadzonych tam zbiorów tradycyjnych, a w jej zaciszu szukają szczególnego rodzaju wytchnienia, chcąc się na pewien czas oderwać od elektronicznych dobrodziejstw współczesnego świata. O takich osobach 
wspomnieli specjaliści realizujący projekt pod nazwą „Library of the future”, zainicjowany przez afiliowane przy American Library Association Center for the Future of Libraries. Na stronie „Library of the future” wskazane mianowicie zostały zaobserwowane w świecie procesy i zjawiska (trends), które mogą mieć wpływ na działalność bibliotek i powinny być uwzględniane w ich działaniach. Jeden z 25 omówionych tam trendów umieszczono pod hasłem unplugged. Specjaliści z ALA twierdzą bowiem, że osobom, które z przyczyn zawodowych czy prywatnych są uzależnione od technologii informacyjnych, grozi poznawcze przeciążenie, więc dla odreagowania i utrzymania pewnej równowagi może być dla nich korzystne okazjonalne przebywanie w miejscach nie posiadających połączenia z siecią. Jako przykład wskazuje się tu branżę hotelarską. Oczywiście większość hoteli reklamuje się podając informację, że zapewniają stały i bezpłatny dostęp do Internetu, ale są i takie hotele, które próbują przyciągnąc inny rodzaj klienta, podając wyraźnie w swej ofercie niczym atut, że dany hotel jest całkowicie poza zasięgiem sieci. Na tej podstawie analitycy z Center for the Future of Libraries uznali, że biblioteki również powinny brać pod uwagę potrzeby osób chcących czasem pozostać unplugged i organizować w przestrzeni biblioteki miejsca pozostające poza zasięgiem sieci i nowych technologii ${ }^{1}$.

Pozostawanie w bibliotece poza zasięgiem sieci, a zwłaszcza sieci bezprzewodowych, może być oczywiście w pewnych sytuacjach pożądane, ale funkcjonalnością oczekiwaną jednak przez większość użytkowników będzie rozwiązanie, w którym cały budynek biblioteki objęty zostanie zasięgiem lokalnej sieci bezprzewodowej WLAN (Wireless Local Area Network, przede wszystkim w standardzie Wi-Fi) o odpowiedniej mocy sygnału i przepustowości łącza. Należy docenić propozycję specjalistów z ALA, by dostrzegać także potrzeby osób potrzebujących niekiedy pozostawać unplugged, ale jest to głos o uznanie potrzeb pewnej mniejszości.

Tym bardziej o mniejszości czy wręcz bardzo wąskim marginesie można mówić, cytując wypowiedzi osób ostrzegających przed elektromagnetycznym smogiem i postulujących niekiedy, by biblioteki pozostawić strefami wolnymi od Wi-Fi z powodu zagrożeń dla zdrowia ludzi. Głosy takie słyszy się zresztą coraz rzadziej, gdyż nie znajdują one potwierdzenia w badaniach naukowych. Na przykład w 2007 r. obiegła Internet wiadomość, że dyrektorka biblioteki jednego z amerykańskich collegów w Nowym Meksyku podała się do dymisji (w grudniu 2006 r.) po tym, jak władze uczelni postanowiły uruchomić w bibliotece uczelnianej usługę Wi-Fi. W tekście opublikowanym na ten temat w periodyku „Library HiTech News” podano wówczas, że nie była to pierwsza

\footnotetext{
${ }^{1}$ Library of the future - Unplugged, American Library Association. Center for the Future of Libraries, http://www.ala.org/transforminglibraries/future/trends/unplugged, [dostęp: 18.04.2017].
} 
tego typu reakcja wśród amerykańskich bibliotekarzy, i że nie brakuje osób przekonanych, iż zawód bibliotekarza staje się zawodem podwyższonego ryzyka, gdyż praca wymagająca długotrwałego przebywania w chmurze Wi-Fi przynosi niekorzystne skutki dla zdrowia człowieka. W swoim oświadczeniu o powodach rezygnacji owa dyrektorka stwierdziła, że w tym proteście nie chodziło tylko o jej własne zdrowie, ale też o ogólną ideę otwartości bibliotek na wszystkich użytkowników. Uznała bowiem, że obejmowanie bibliotek zasięgiem Wi-Fi uniemożliwia osobom z problemami kardiologicznymi i neurologicznymi korzystanie z bibliotek ${ }^{2}$. Było to oczywiste nieporozumienie. Rzeczywiście często $\mathrm{w}$ wypowiedziach na temat szkodliwości fali radiowej pojawia się jako argument przykład osób mających wszczepione rozruszniki serca, którym zaleca się unikania miejsc z oddziaływaniem silnego pola elektromagnetycznego, które mogłoby zakłócić pracę takiego rozrusznika. Ale mowa tu o silnym polu elektromagnetycznym (na przykład gdy przebywa się w pobliżu transformatorów). Pole, jakie wytwarzają sprzęty codziennego użytku, a więc także routery Wi-Fi, nie jest niebezpieczne dla osób z rozrusznikami. Owszem, zaleca się takim osobom, by nie nosiły telefonów komórkowych w kieszeni na piersi, i by rozmawiały przez telefon, trzymając go raczej w prawej ręce. Ale w odległości $30 \mathrm{~cm}$ od rozrusznika telefon nie powinien mieć już żadnego wpływu na prawidłową pracę urządzenia. Przebywanie w bibliotece w zasięgu lokalnej sieci bezprzewodowej też więc nie jest groźne, tak jak nie szkodzi zdrowiu (przynajmniej fizycznemu) słuchanie radia.

W bibliotekach zatem, tak jak w wielu innych miejscach użyteczności publicznej, dla wygody użytkowników uruchamia się kolejne hotspoty z bezpłatnym dostępem do Internetu, czasem wymagające logowania, a czasem całkowicie otwarte $\mathrm{z}$ anonimowym dostępem do sieci. Należy zauważyć, że biblioteka może pozostawać w zasięgu bezpłatnej sieci bezprzewodowej, nie tworząc sieci własnej. Strefy bezpłatnego dostępu do Internetu kojarzą się przede wszystkim z dużymi miastami i miejscami takimi, jak restauracje, puby, hipermarkety, dworce i urzędy. Tymczasem coraz częściej takie strefy powstają także w mniejszych jednostkach administracyjnych, obejmując cały obszar danej miejscowości. Jednostka samorządu terytorialnego, która zamierza stworzyć taką strefę na swoim terenie, musi jednak spełnić kilka warunków, a przede wszystkim uzyskać zgodę Urzędu Komunikacji Elektronicznej (UKE). Wydaje on swoje decyzje na podstawie ustawy o wspieraniu rozwoju usług i sieci telekomunikacyjnych z 2010 r. $^{3}$ Pierwsza taka decyzja zapadła

${ }^{2}$ Library director resigns because of WiFi, „Library Hi Tech News” 2007, vol. 24, no 2, s. $30-31$.

${ }^{3}$ Ustawa z dnia 7 maja 2010 r. o wspieraniu rozwoju ustug $i$ sieci telekomunikacyjnych, „Dziennik Ustaw” 2010, nr 106, poz. 675. 
w grudniu 2010 r. w odpowiedzi na wniosek gminy Przasnysz ${ }^{4}$. UKE wydaje poszczególnym gminom zgodę na stworzenie strefy bezpłatnego dostępu do bezprzewodowego Internetu, ustalając jednak pewne limity w zakresie ilości i szybkości przesyłu danych. Urząd stabilizuje w ten sposób rynek telekomunikacyjny, bowiem brak limitów uderzyłby w operatorów oferujących dostęp do szybkich sieci na zasadach komercyjnych. Przy limicie ustalonym przez UKE użytkownik sieci może wysłać maila, uzyskać informacje o rozkładzie PKS, sprawdzić godziny otwarcia urzędu czy biblioteki, ale niewiele ponad to.

Dlatego biblioteki, jeśli nawet znajdują się w zasięgu bezpłatnych sieci miejskich, uruchamiają własne hotspoty, dając swoim użytkownikom większy komfort korzystania z sieci. Bezprzewodowe sieci lokalne są więc udogodnieniem oferowanym już nie tylko w dużych bibliotekach naukowych i największych bibliotekach publicznych. Informacje na ten temat podają na swoich stronach internetowych także mniejsze biblioteki publiczne średniego szczebla - powiatowe i miejskie, a także coraz częściej małe biblioteki gminne. Fakt ten jednak w żaden sposób nie zaskakuje, bo do budowy lokalnej sieci bezprzewodowej wiele nie trzeba. Koszt zakupu średniej jakości routera, który pozwoli objąć zasięgiem Wi-Fi cały budynek biblioteki gminnej nie jest wysoki. Zatem warunkiem podstawowym jest, by biblioteka była skomputeryzowana w podstawowym zakresie i miała dostęp do Internetu.

Informacje o dostępie do Internetu w bibliotekach publicznych, a w tym także o możliwości korzystania z sieci bezprzewodowej, znaleźć można w publikowanych od ponad dekady raportach Komisji Automatyzacji Zarządu Głównego Stowarzyszenia Bibliotekarzy Polskich (obecnie pod nazwą Komisja Nowych Technologii). Raport z 2010 r. wykazał więc, że w grupie bibliotek powiatowych liczba bibliotek udostępniających bezprzewodowy Internet czytelnikom wynosiła 149 placówek, a z raportu z 2012 r. wynikało, że tych placówek było już $173^{5}$. Jeszcze większy postęp zanotowano wówczas w grupie najmniejszych bibliotek $\mathrm{w}$ miastach $\mathrm{i}$ na wsi. Łącznie według raportu z 2010 r. w obu tych kategoriach bezprzewodowy Internet udostępniało 1458 bibliotek, a dwa lata późniejszy raport pokazał, że już 2225 bibliotek w obu kategoriach oferowało bezprzewodowy dostęp do sieci ${ }^{6}$. Mimo znaczącego liczbowo postępu zanotowanego w latach 2010-2012, w ujęciu procentowym

\footnotetext{
${ }^{4}$ Decyzja dla Gminy Miasto Przasnysz, Urząd Komunikacji Elektronicznej, https://www. uke.gov.pl/decyzja-dla-gminy-miasto-przasnysz-6637\#, [dostęp: 14.04.2017].

${ }^{5}$ K. Winogrodzka, Raport o stanie komputeryzacji bibliotek publicznych 2012, [w:] Modele wspótpracy bibliotek publicznych. Czy razem możemy więcej, szybciej, lepiej? X Ogólnopolska Konferencja „Automatyzacja bibliotek publicznych”. Warszawa, 7-8 listopada 2012 r., Warszawa 2013, s. 16.
}

${ }^{6}$ Ibidem, s. 20. 
okazywało się, że w 2012 r. niespełna 1/3 bibliotek publicznych miała w ofercie dla użytkowników bezprzewodowy dostęp do Internetu. $\mathrm{Z}$ ostatniego jak dotąd raportu z 2015 r. wynikało zaś, że już blisko 45\% bibliotek publicznych oferowało korzystanie z Internetu bezprzewodowego ${ }^{7}$.

Warto w tym miejscu wspomnieć jeszcze o kwestii pobierania opłat za dostęp do Internetu. Tak jak oczekiwanym standardem staje się dostęp bezprzewodowy, tak również standardem stała się rezygnacja z pobierania opłat za korzystanie z sieci. Należy wszak przypomnieć, że jeszcze stosunkowo niedawno - co wynika z raportu z 2012 r. - opłaty nie były rzadkością. Co prawda żadna wówczas biblioteka wojewódzka opłaty nie pobierała, ale już na szczeblu powiatowym było wciąż ponad 10\% placówek, które za usługę dostępu do Internetu jeszcze opłatę pobierały ${ }^{8}$.

Dostęp do lokalnych sieci bezprzewodowych w bibliotekach publicznych staje się więc standardem obowiązującym, tak jak wcześniej stał się standardem w bibliotekach naukowych, a przede wszystkim w bibliotekach szkół wyższych.

Przedstawiony poniżej przegląd serwisów internetowych w bibliotekach wszystkich 19 polskich uniwersytetów klasycznych (18 uczelni publicznych plus KUL) pokazuje, że w większości z tych bibliotek jest możliwość korzystania z sieci Eduroam, choć jest kilka bibliotek, w których sieć Eduroam nie jest dostępna, mimo że macierzysta uczelnia uczestniczy w tym porozumieniu. Projekt Eduroam jest międzynarodową federacją krajowych federacji tworzonych przez ośrodki naukowe, a głównie akademickie. Polska część projektu Eduroam opiera się na ogólnopolskiej akademickiej sieci komputerowej Pionier. Zgodnie z podstawowym założeniem roamingu (stąd nazwa Eduroam - educational roaming) instalacja certyfikatu Eduroam sprawi, że pracownik akademicki lub student, który po tejże instalacji korzysta bez przeszkód z sieci Eduroam w obrębie swojej uczelni, powinien też uzyskać automatyczne połączenie z tą siecią w każdej innej uczelni, która bierze udział w projekcie.

\footnotetext{
${ }^{7}$ B. Budyńska, Stan komputeryzacji bibliotek publicznych, „Biuletyn EBIB” 2015, nr 9, http://open.ebib.pl/ojs/index.php/ebib/article/download/403/568, s. 8, [dostęp: 18.04.2017].

${ }^{8} \mathrm{~K}$. Winogrodzka, op. cit., s. 16; osobliwe rozwiązanie stosuje w tym zakresie Biblioteka Miejska w Grudziądzu, która na swojej stronie WWW informuje, że co prawda w Bibliotece Głównej oraz we wszystkich filiach można nieodpłatnie skorzystać z Internetu, ale w punkcie mówiącym o bezprzewodowym dostępie do sieci podaje informację, że „użytkownicy w zamian za darmowe połączenie z Internetem oglądają przed każdym uruchomieniem sesji 30 sekund reklamy"; Biblioteka Miejska w Grudziądzu, http://www.biblioteka.grudziadz.pl/, [dostęp: 20.04.2017].
} 
W większości bibliotek uniwersyteckich w Polsce bezprzewodowy dostęp do sieci uzyskać można przynajmniej na dwa sposoby - albo poprzez Eduroam, albo jakąś alternatywną sieć WLAN. Tą alternatywną siecią może być albo sieć ogólnouczelniana, albo też lokalna sieć biblioteczna.

To, jak ważnym udogodnieniem jest bezprzewodowy dostęp do sieci w bibliotece, pokazuje informacja na stronie Biblioteki Jagiellońskiej (BJ), mówiąca o tym, że w czytelni są ogółem 164 miejsca, ale tylko „2 komputery z dostępem do Internetu", co oznacza, że większość osób pracujących w czytelni musi, gdy jest taka potrzeba, korzystać z Internetu bezprzewodowo. Co prawda $\mathrm{z}$ informacji uzyskanej wprost od pracownika czytelni BJ wynika, że informacja na stronie jest już nieco nieaktualna, bo faktycznie komputerów $\mathrm{z}$ dostępem stacjonarnym jest $\mathrm{w}$ czytelni BJ pięć, ale nie robi to specjalnie różnicy przy ponad 160 miejscach ogółem. Bezprzewodowy dostęp do sieci ma więc istotne znaczenie, a w Bibliotece Jagiellońskiej dostęp ten uzyskuje się albo poprzez sieć Eduroam albo sieci otwarte UJ-open i BJ-open.

W Bibliotece Uniwersyteckiej w Warszawie (BUW) można bezprzewodowo łączyć się z Internetem, korzystając z kilku otwartych sieci Wi-Fi, a więc nie wymagających podania klucza zabezpieczeń sieciowych, przy czym nie jest to całkowicie otwarty dostęp. W BUW użytkownicy są przede wszystkim w zasięgu uniwersyteckiej sieci Eduroam. Korzystanie z tej sieci na UW, tak jak w innych ośrodkach akademickich i naukowych, następuje po utworzeniu w urządzeniu użytkownika profilu sieci i zapisaniu certyfikatu, co wymaga przy pierwszym logowaniu pełnego uwierzytelnienia przez podanie swojego numeru pesel i hasła do uniwersyteckiego systemu USOS. Jeśli w urządzeniu użytkownika sieć Eduroam będzie zapisana jako domyślna $\mathrm{z}$ opcją łączenia automatycznego, wówczas każdorazowe późniejsze znalezienie się w zasięgu tej sieci spowoduje natychmiastowe $\mathrm{z}$ nią połączenie bez potrzeby autoryzacji. Alternatywną siecią oferowaną przez BUW jest sieć BUW.Hotspot ${ }^{10}$, która jest przeznaczona przede wszystkim dla pracowników i studentów uczelni będących zarejestrowanymi użytkownikami Biblioteki, gdyż użytkownik loguje się podając numer ważnej karty bibliotecznej i hasło do konta użytkownika BUW. Dla osób spoza społeczności akademickiej, a więc nie mogących korzystać ani z Eduroam, ani z BUW.Hotspot, możliwy jest w BUW dostęp do sieci UWGuestWiFi, ale dopiero po zalogowaniu się do utworzonego wcześniej konta,

\footnotetext{
${ }^{9}$ Biblioteka Jagiellońska. Czytelnia Gtówna (Lectorium), http://www.bj.uj.edu.pl/czytelniaglowna, [dostęp: 18.04.2017].

${ }^{10}$ Opcjonalnie w różnych częściach pokaźnego budynku BUW działają z różną siłą sygnału sieci dla jego poszczególnych części, jak BUW.Hol, BUW.Kab.
} 
gdzie podczas rejestracji należy podać swoje imię i nazwisko, swój adres mailowy oraz ... adres e-mail pracownika Uniwersytetu, który potwierdzi ważność konta!

Podobne rozwiązania funkcjonują w Bibliotece Uniwersyteckiej w Poznaniu i Bibliotece Uniwersytetu Łódzkiego (BUŁ). Obie biblioteki są przede wszystkim objęte działaniem sieci Eduroam, są też jednak możliwości alternatywne. W Poznaniu dla osób nie korzystających z Eduroam Uniwersytetu Adama Mickiewicza Punkt Informacyjny w Bibliotece Uniwersyteckiej zakłada tymczasowy identyfikator dostępu gościnnego. W Łodzi, jak podaje strona internetowa BUŁ, ,kod dostępu uzyskuje się za okazaniem ważnej karty bibliotecznej lub legitymacji studenckiej u dyżurującego bibliotekarza"11.

Centrum Informacji Naukowej i Biblioteka Akademicka (CINiBA) na Uniwersytecie Śląskim jest przykładem biblioteki uniwersyteckiej, której uczelnia uczestniczy w projekcie Eduroam, ale która dostępu do tej sieci jeszcze nie ma. Z ogólnouczelnianej informacji wynika, że dostęp do sieci Eduroam jest możliwy w kilkunastu lokalizacjach w Katowicach, a także w kilku lokalizacjach w Sosnowcu, Cieszynie i Chorzowie. Jednak na liście miejsc z zasięgiem sieci Eduroam nie ma Centrum Informacji Naukowej i Biblioteki Akademickiej. $\mathrm{Z}$ informacji przekazanej przez pracownicę Informatorium CINiBA wynika, że osoba chcąca korzystać z Internetu musi każdorazowo zgłaszać się do Informatorium w celu uzyskania karteczki z loginem i hasłem do sieci pod nazwą CINIBA-EXT. Należy jednak zaznaczyć, że w gmachu CINiBA jest ponad 100 stanowisk z przewodowym dostępem do Internetu.

Identyczna sytuacja ma miejsce w Uniwersytecie Szczecińskim, gdzie ogólnouczelniana informacja o zasięgu sieci Eduroam podaje 8 lokalizacji na terenie Szczecina, w których ta sieć jest dostępna ${ }^{12}$, ale w tym wykazie nie ma adresu Biblioteki Głównej Uniwersytetu Szczecińskiego (BGUS), a z informacji przekazanej przez pracownicę Czytelni BGUS wynika, że chcąc korzystać z bezprzewodowego dostępu do sieci, należy zgłosić się do pracownika czytelni w celu uzyskania loginu i hasła sieciowego.

Podobnie jest na Uniwersytecie Rzeszowskim (UR), bo w wielu lokalizacjach w Rzeszowie w budynkach Uniwersytetu działa sieć Eduroam, jednak Biblioteka UR jeszcze nie znajduje się w zasięgu tej sieci. Mimo to, strona WWW Biblioteki informuje o dostępie bezprzewodowym we wszystkich

\footnotetext{
${ }^{11}$ Biblioteka Uniwersytetu Łódzkiego, Udostępnianie, http://www.lib.uni.lodz.pl/idx=udos, [dostęp: 18.04.2017].

${ }^{12}$ Uniwersytet Szczeciński. Uczelniane Centrum Informatyczne. Eduroam, http://uci.usz edu.pl/infrastruktura/eduroam/, [dostęp: 18.04.2017].
} 
swoich czytelniach w Strefie Wi-Fi BUR, a dodatkowo pracownik Oddziału Zarządzania Systemami Informatycznymi przekazał informację, że jest to dostęp całkowicie otwarty i nie wymagający autoryzacji!

Nie można z przekonaniem stwierdzić, że wszystkie biblioteki uniwersyteckie należycie informują na swoich stronach WWW o zasadach korzystania z lokalnej sieci bezprzewodowej. Najpełniejszą informację znajdziemy w serwisach internetowych Biblioteki Uniwersyteckiej w Toruniu, Biblioteki Uniwersytetu Gdańskiego i Centrum Informacji Naukowej i Biblioteki Akademickiej na Uniwersytecie Śląskim. W Toruniu pracownicy i studenci korzystają z Eduroam, osoby spoza Uniwersytetu Mikołaja Kopernika mogą zaś korzystać z lokalnej uniwersyteckiej sieci bezprzewodowej, logując się do niej jako goście, jednak konieczna jest procedura autoryzacji. W Gdańsku również zalecanym przez bibliotekę uczelnianą sposobem korzystania $\mathrm{z}$ bezprzewodowego Internetu jest łączenie się przez sieć Eduroam.

W pozostałych bibliotekach uniwersyteckich informacja o możliwości korzystania $\mathrm{z}$ bezprzewodowego Internetu jest albo zdawkowa, albo nie ma jej wcale. Można to bagatelizować i argumentować, że dla ludzi z pokolenia cyfrowych tubylców może nie mieć to specjalnego znaczenia, bo przeciętny użytkownik raczej potrafi na swoim urządzeniu mobilnym wyświetlić listę dostępnych sieci bezprzewodowych i spośród nich wybrać tę właściwą. $Z$ pewnością jednak są osoby nie posiadające takiej sprawności. Mogą one nie wiedzieć, którą z dostępnych sieci wybrać i jak przejść ewentualny proces autoryzacji. Odpowiednia informacja na stronie WWW biblioteki może więc być w takich sytuacjach pomocna. O ile jeszcze krótkie informacje na ten temat można znaleźć na stronach Biblioteki Uniwersyteckiej w Warszawie, Biblioteki Jagiellońskiej, Biblioteki Uniwersyteckiej w Białymstoku, Biblioteki UMCS czy Biblioteki Uniwersyteckiej w Olsztynie (najczęściej z odesłaniem do ogólnouniwersyteckiego systemu informacji o funkcjonowaniu sieci Eduroam), to w pozostałych bibliotekach serwisy internetowe nie podają bliższych informacji o możliwości korzystania z lokalnej sieci bezprzewodowej. Choć takich wskazówek nie ma na stronach Biblioteki Głównej Uniwersytetu Opolskiego, Biblioteki Uniwersytetu Kazimierza Wielkiego w Bydgoszczy, Biblioteki Uniwersyteckiej w Kielcach i Biblioteki Katolickiego Uniwersytetu Lubelskiego, to z ogólnouczelnianej informacji podającej lokalizacje w Opolu, Bydgoszczy, Kielcach i Lublinie (KUL) dotyczącej zasięgu sieci Eduroam wynika, że obejmuje ona także budynki tamtejszych bibliotek uniwersyteckich. Dotyczy to również Biblioteki Uniwersytetu Zielonogórskiego, jednak - jak wynika z informacji uzyskanej w Dziale Obsługi Informatycznej - studenci i pracownicy UZ korzystają z bezprzewodowego dostępu do sieci przede wszystkim łącząc się z otwartą siecią o nazwie UZ.Zgora.pl. 
Strona Eduroam.pl wśród lokalizacji objętych zasięgiem tej sieci w jednostkach Uniwersytetu Wrocławskiego nie wymienia budynku Biblioteki Uniwersyteckiej. Jednak z informacji uzyskanej od pracownika OIN wynika, że podstawową siecią dla studentów i pracowników korzystających z biblioteki jest właśnie sieć Eduroam, zaś osoby spoza uczelni mogą korzystać z łączności bezprzewodowej po tym, jak od pracownika czytelni dostaną na kartce tymczasowy login i hasło dostępu do sieci pod nazwą Czytelnia.

$\mathrm{Z}$ przedstawionego przeglądu serwisów internetowych bibliotek uniwersyteckich wynika, że kilka z nich stosuje dość kłopotliwe rozwiązanie z każdorazowym pobieraniem jednorazowego loginu i hasła dostępu do sieci Wi-Fi u bibliotekarza dyżurującego $\mathrm{w}$ informatorium lub czytelni. W takiej sytuacji tym bardziej dostrzega się zaletę sieci Eduroam, która raz zapisana w urządzeniu użytkownika nie powinna wymagać kolejnych autoryzacji.

Łatwiej mają pod tym względem osoby odwiedzające Bibliotekę Uniwersytetu Kardynała Stefana Wyszyńskiego (UKSW). Zaznaczyć jednak na wstępie należy, co jest niewątpliwie pewnym zaskoczeniem, że UKSW jest jedynym z klasycznych uniwersytetów w Polsce, który jeszcze nie przystąpił do projektu Eduroam. Jednak strona Biblioteki UKSW informuje o możliwości korzystania z Wi-Fi, a z informacji uzyskanej w Centrum Systemów Informatycznych UKSW wynika, że studenci logujący się numerem indeksu i hasłem do uczelnianego systemu informatycznego mogą korzystać ze wszystkich funkcjonalności bezprzewodowego dostępu do Internetu, zaś goście mają co prawda dostęp otwarty (bez haseł i autoryzacji), ale nie korzystają ze wszystkich funkcjonalności systemu.

Przypadek UKSW i innych bibliotek, w których dostępne są sieci całkowicie otwarte i nie stosujące żadnej procedury autoryzacji, każe zadać pytanie o zasadność takiego rozwiązania i związane z tym bezpieczeństwo.

Jako przykład dużej biblioteki naukowej, która z kolei mogłaby służyć za wzór polskim bibliotekom w zakresie szczegółowości informacji o zasadach korzystania $\mathrm{z}$ bezprzewodowego dostępu do sieci, stosującej jednocześnie określone procedury weryfikacji użytkowników, można wskazać British Library (BL) w Londynie. Informacja o możliwościach uzyskania połączenia z siecią bezprzewodową $\mathrm{w}$ gmachu BL zajmuje w serwisie internetowym tej biblioteki wyjątkowo dużo miejsca ${ }^{13}$. BL usługę wolnego dostępu do Internetu przez sieć bezprzewodową uruchomiła w październiku 2008 r. ${ }^{14}$ Obecnie w British

${ }^{13}$ Zob. Wifi at the British Library, http://www.bl.uk/aboutus/stpancras/wifi/, [dostęp: 18.04.2017].

${ }^{14}$ Free WiFi Internmet Access At British Library, „Managing Information” 2008, vol. 15, no 3, s. 36 . 
Library można skorzystać z Wi-Fi będąc nie tylko zarejestrowanym użytkownikiem, który, mając ważną kartę biblioteczną, utworzy konto, ale również jako niezarejestrowany użytkownik (visitor). Wystarczy wówczas założyć konto dostępu przez Wi-Fi, gdzie należy podać swoje imię i nazwisko oraz adres email. Na ten adres system wyśle link do logowania, który należy wykorzystać w ciągu 15 minut $^{15}$.

Biblioteka Narodowa (BN) w Warszawie udostępniła swoim użytkownikom sieć bezprzewodową obejmującą cały budynek kilka lat po tym, jak zrobiła to British Library. Pierwszą różnicą między obiema bibliotekami, jaką się dostrzega w kontekście dostępu do lokalnej sieci bezprzewodowej, jest ilość informacji na ten temat zawarta na stronach WWW. Zostało już wyżej stwierdzone, że serwis internetowy londyńskiej biblioteki jest pod tym względem bardzo rozbudowany - została temu poświęcona cała strona z podstronami, podająca informacje o kolejnych czynnościach, jakie należy wykonać, by się pomyślnie zalogować. Na stronie biblioteki warszawskiej jest tylko jedno zdanie w części serwisu zatytułowanej „Zasoby informacyjne online”, mówiące, że do owych zasobów informacyjnych mają dostęp czytelnicy z ważnymi kartami bibliotecznymi nie tylko z komputerów stacjonarnych, ale też przez Wi-Fi na własnych laptopach. Jednozdaniowa wzmianka na ten temat znajduje się także w „Regulaminie korzystania z Internetu i zasobów cyfrowych w siedzibie Biblioteki Narodowej” umieszczonym w strukturze strony BN w dziale „O BN\Regulaminy”.

Różnicę widać też w procedurze weryfikacji użytkownika próbującego skorzystać z sieci bezprzewodowej. Otóż w Bibliotece Narodowej w Warszawie można się zasadniczo logować do sieci Wi-Fi korzystając z routera dającego w określonej części gmachu najmocniejszy sygnał. Przykładowo, będąc w Czytelni Bibliologicznej można wybrać sieć Czytelnia Bibliologiczna, bo ten sygnał jest tam oczywiście najmocniejszy, a żeby uzyskać dostęp do Internetu, trzeba podać imię, nazwisko, numer karty bibliotecznej i jednym „kliknięciem” zaakceptować regulamin. To standardowa procedura, stosowana $\mathrm{w}$ wielu bibliotekach. Problem polega na tym, choć zapewne większość korzystających nie potraktuje tego jako problem, że w BN działa (a przynajmniej działała w czasie postawania niniejszego artykułu) druga sieć Wi-Fi o nazwie $B N$ Guest, która w ogóle nie wymaga logowania. Wchodząc do niej trzeba tylko zaakceptować regulamin, by uzyskać pełny dostęp do Internetu. Ale na tym nie koniec. Otóż po wyjściu z biblioteki nadal można korzystać bezprzewodowo z sieci BN. Co więcej, przy samym wejściu pojawia się kolejna, trzecia sieć

\footnotetext{
${ }^{15}$ Wifi at the British Library, http://www.bl.uk/aboutus/stpancras/wifi/, [dostęp: 18.04.
} 2017]. 
o nazwie Konferencja (przy wejściu głównym jest sala konferencyjna BN), która nawet nie domaga się akceptacji regulaminu ${ }^{16}$. Jednym słowem, siedząc na ławce przed wejściem do BN można bez żadnych ograniczeń i weryfikacji korzystać z dostępu do Internetu przez lokalną sieć bezprzewodową Biblioteki Narodowej.

Fakt, że niektóre sieci bezprzewodowe Biblioteki Narodowej są całkowicie otwarte, jest być może jednocześnie wythumaczeniem faktu, że BN o tym nie informuje. Wydaje się, że skoro Biblioteka Narodowa daje osobom odwiedzającym ją lub przebywającym w jej pobliżu zupełnie swobodny dostęp do Internetu, to mogłaby odpowiednio zareklamować to udogodnienie. Sarah Houghton-Jan w artykule wyliczającym w 20 punktach zasady promowania biblioteki w sieci, w punkcie nr 10 podała, że jeśli biblioteka oferuje bezprzewodowy dostęp do Internetu, powinna zadbać, by informacja na ten temat znalazła się w katalogach wyliczających hotspoty z otwartym Internetem dostępne $\mathrm{w}$ określonej lokalizacji ${ }^{17}$. Tymczasem informacji na ten temat nie ma ani na stronie WWW BN, ani w dostępnych w sieci wykazach otwartych hotspotów w Warszawie ${ }^{18}$.

Zrozumiałe jest, że całkowicie otwarty bezprzewodowy dostęp do Internetu w BN spotyka się z akceptacją osób odwiedzających bibliotekę i przebywających $w$ jej okolicy. $Z$ drugiej jednak strony, pozwalając na całkowicie anonimowe korzystanie $\mathrm{z}$ bezprzewodowego dostępu do Internetu, osoba lub instytucja świadcząca taką usługę musi się liczyć nawet $\mathrm{z}$ ewentualnymi pozwami, gdyby się okazało, że użytkownicy korzystają z owej anonimowości na granicy prawa lub je przekraczając.

Może się jednak z czasem okazać, że zupełnie otwarty i anonimowy dostęp do sieci, a więc ani nie wymagający wprowadzenia klucza zabezpieczeń sieci, ani nie przewidujący żadnej formy uwierzytelniania, stanie się niemożliwy. Wiele w tym względzie zależy od tego, czy do prawodawstwa krajów unijnych zostaną wprowadzone określone zmiany po wyroku Trybunału Sprawiedliwości UE (TSUE) w sprawie C-484/14. Wyrok ten zapadł 15 września 2016 r., a dotyczył sporu sądowego pomiędzy niemieckim przedsiębiorcą

${ }^{16}$ Warto zauważyć, że podobnie jak w BN również w Bibliotece Uniwersyteckiej w Warszawie działa sieć dla uczestników często organizowanych na III poziomie konferencji pod nazwą BUW.Konferencja. Z tą jednak różnicą, że w BUW dostęp jest zabezpieczony hasłem.

${ }^{17}$ Oryg. List your library in free wifi directories; S. Houghton-Jan, Twenty Steps to Marketing Your Library Online, ,Journal of Web Librarianship” 2007, vol. 1, no 4, s. 85.

${ }^{18} \mathrm{~W}$ archiwum strony BN znaleźć można jedynie informację, że hotspot Biblioteki Narodowej zajął niegdyś wysokie miejsce w rankingu warszawskich hotspotów. Zob. Hotspot BN trzeci w Warszawie!, Biblioteka Narodowa, http://www.tak.waw.pl/aktualnosci/39-hotspot-bntrzeci-w-warszawie!.html, [dostęp: 12.04.2017]. 
Tobiasem Mc Faddenem a niemieckim oddziałem firmy Sony Music Entertainment. Spór powstał jeszcze w 2010 r., gdy firma Sony Music stwierdziła, że w Internecie został bezpłatnie i z naruszeniem praw autorskich udostępniony utwór muzyczny, którego była producentem. Stwierdzono dodatkowo, że bezprawne udostępnienie utworu nastąpiło poprzez bezprzewodową sieć lokalną, której operatorem był Tobias Mc Fadden. Potwierdziło się zatem, że Mc Fadden w swoim sklepie w miejscowości Gauting pod Monachium uruchomił dla klientów całkowicie otwarty hotspot z siecią Wi-Fi wskazaną przez Sony. W pozwie przeciwko Mc Faddenowi Sony Music zażądała wobec tego wypłaty odszkodowania. Mc Fadden tłumaczył, że sam nie dokonał naruszenia prawa autorskiego, ale nie wykluczył, że mógł tego dokonać któryś z klientów jego otwartej sieci Wi-Fi. Sąd w Monachium w 2014 r. uwzględnił powództwo firmy Sony, wobec tego Mc Fadden odwołał się od wyroku. W konsekwencji sąd odwoławczy postanowił zwrócić się do Trybunału Sprawiedliwości w Luksemburgu z pytaniami prejudycjalnymi o wykładnię prawa unijnego odnośnie rozpatrywanej sprawy. Wyrok TSUE, na podstawie którego miał swój wyrok oprzeć sąd okręgowy w Monachium, był tym razem korzystny dla Mc Faddena. TSUE uznał bowiem, że osoba będąca właścicielem praw autorskich nie może „żądać od dostawcy dostępu do sieci telekomunikacyjnej odszkodowania na tej podstawie, iż jeden z tych dostępów został użyty przez osoby trzecie do naruszenia jej praw". Innymi słowy, Sony nie może domagać się od Mc Faddena odszkodowania za to, że użytkownik sieci Wi-Fi uruchomionej przez Mc Faddena podczas korzystania z tej sieci naruszył prawo autorskie. Jednocześnie TSUE uznało, że sąd może jednakowoż nakazać osobie udostępniającej łącze internetowe do zabezpieczenia tego łącza hasłem w celu ,uniemożliwienia osobom trzecim publicznego udostępniania za pomocą tego łącza internetowego określonego utworu lub jego części chronionych prawem autorskim"19.

Wyrok TSUE jeszcze oczywiście nie oznacza, że na obszarze Unii Europejskiej wszystkie hotspoty dające anonimowy dostęp do Internetu zostaną zabezpieczone hasłami i zaczną stosować procedury uwierzytelniania. Oznacza to jednak tyle, że gdyby na przykład jakaś biblioteka została pozwana przez właściciela praw autorskich do utworu rozpowszechnianego w jej niezabezpieczonej sieci bezprzewodowej z tytułu naruszenia praw autorskich, to co prawda biblioteka nie może zostać ukarana wypłatą odszkodowania na rzecz właściciela praw autorskich, może być jednak zobowiązana przez sąd do zabezpieczenia swojej sieci hasłem.

${ }^{19}$ Wyrok Trybunału (trzecia izba) z dnia 15 września 2016 r. (...) w sprawie C-484/14 (...) Tobias Mc Fadden przeciwko Sony Music Entertainment Germany GmbH, http://curia.europa. eu/juris/liste.jsf?num=C-484/14\#, [dostęp: 12.04.2017]. 
Bezprzewodowy dostęp do Internetu w bibliotece to niejako - trawestując tytuł opowiadania Marka Hłaski - pierwszy krok w biblioteczną chmurę. Hotspoty w bibliotekach różnych typów i różnych szczebli przestają być czymś wyjątkowym, stają się usługą podstawową. Co więcej, obok określenia „hotspot w bibliotece" pojawiło się też podobnie brzmiące sformułowanie „hotspot z biblioteki”, a wraz z nim marketingowo nośne hasło „wypożycz Internet w bibliotece!". Chodzi tu o możliwość całkowicie bezpłatnego wypożyczania w bibliotekach, na tych samych zasadach jak wypożycza się książki, niewielkich mobilnych hotspotów z zainstalowanymi kartami sim. Takie urządzenie pozwala użytkownikowi (a także jeszcze przynajmniej kilku osobom) podłączyć do sieci bezprzewodowej swój tablet czy laptop i pozostawać online w każdym miejscu, gdzie jest zasięg operatora telekomunikacyjnego, którego karta sim znajduje się w urządzeniu. Zapewne pozostanie to usługą świadczoną przez nieliczne biblioteki, tak jak na przykład nieliczne biblioteki wypożyczają drony. Tym bardziej, że funkcję hotspotu może uruchomić prawie każdy posiadacz smartfonu. Ale rejestry wypożyczeń tych urządzeń w bibliotekach, które to oferują, świadczą o dużym zainteresowaniu ze strony użytkowników ${ }^{20}$. Biblioteki, które wprowadziły tę usługę, pokazują tylko dobitnie, że dostrzegają potrzeby swoich użytkowników, zwłaszcza tych z pokolenia born digital, którzy w zasięgu sieci bezprzewodowych chcą być i w bibliotece, i poza nią.

\section{Bibliografia}

Budyńska B., Stan komputeryzacji bibliotek publicznych, „Biuletyn EBIB” 2015, nr 9 (162), http://open.ebib.pl/ojs/index.php/ebib/article/download/403/568, [dostęp: 18.04.2017].

Free WiFi Internmet Access At British Library, „Managing Information” 2008, vol. 15, no 3 , s. 36.

Houghton-Jan S., Twenty Steps to Marketing Your Library Online, „Journal of Web Librarianship" 2007, vol. 1, no 4, s. 81-90.

Library of the future - Unplugged, American Library Association. Center for the Future of Libraries, http://www.ala.org/transforminglibraries/future/trends/unplug ged, [dostęp: 18.04.2017].

Library director resigns because of WiFi, „Library Hi Tech News” 2007, vol. 24, no 2, s. $30-31$.

Winogrodzka K., Raport o stanie komputeryzacji bibliotek publicznych 2012, [w:] Modele wspótpracy bibliotek publicznych. Czy razem możemy więcej, szybciej,

${ }^{20}$ Zob. np. Kitchener Public Library (Canada) - Borrow the Internet: http://www.kpl.org/ hotspot. 
lepiej? X Ogólnopolska Konferencja „Automatyzacja bibliotek publicznych”. Warszawa, 7-8 listopada 2012 r., Warszawa 2013, s. 9-31.

Wyrok Trybunatu (trzecia izba) z dnia 15 września 2016 r. (...) w sprawie C-484/14 (...) Tobias Mc Fadden przeciwko Sony Music Entertainment Germany GmbH3, http://curia.europa.eu/juris/liste.jsf?num=C-484/14\#, [dostęp: 12.04.2017]. 